Revista de Metalurgia 52(2)

April-June 2016, e070

ISSN-L: 0034-8570

doi: http://dx.doi.org/10.3989/revmetalm.070

\title{
Statistical study to determine the effect of carbon, silicon, nickel and other alloying elements on the mechanical properties of as-cast ferritic ductile irons
}

\author{
Jacques Lacaze ${ }^{\mathrm{a}}$, Jon Sertucha ${ }^{\mathrm{b}, \bowtie}$, Pello Larrañaga ${ }^{\mathrm{b}}$, Ramón Suárez \\ ${ }^{a}$ CIRIMAT, Université de Toulouse, ENSIACET, CS 44362, F-31030 Toulouse cedex 4, France \\ ${ }^{b}$ Ingeniería, I+D y Procesos Metalúrgicos, IK4-AZTERLAN, Aliendalde Auzunea 6, E-48200 Durango (Bizkaia), Spain \\ Corresponding author: jsertucha@azterlan.es
}

Submitted: 13 December 2015; Accepted: 17 May 2016; Available On-line: 27 June 2016

\begin{abstract}
There is a great interest in fully ferritic ductile irons due to their structural homogeneity, remarkable ductility and good response when machining. On the other hand the wide variety of raw materials available in foundry plants becomes a problem when controlling the chemical composition of the manufactured alloys. The present work shows a statistical study about the effect of different C, Si, Ni contents and other minor elements on structural and mechanical properties of a group of ferritic ductile iron alloys. A set of equations are finally presented to predict room temperature mechanical properties of ferritic ductile irons by means of their chemical composition and pearlite content.
\end{abstract}

KEYWORDS: As-cast ferritic ductile cast irons; Carbon; Mechanical properties; Nickel; Silicon

Citation / Cómo citar este artículo: Lacaze, J., Sertucha, J., Larrañaga, P., Suárez, R. (2016) "Statistical study to determine the effect of carbon, silicon, nickel and other alloying elements on the mechanical properties of as-cast ferritic ductile irons". Rev. Metal. 52 (2):e070. doi: http://dx.doi.org/10.3989/revmetalm.070.

RESUMEN: Influencia del carbono, silicio, níquel y otros elementos de aleación sobre las propiedades mecánicas de la fundición con grafito esferoidal en bruto de colada. Las fundiciones con grafito esferoidal de matriz totalmente ferrítica tienen gran interés debido a su homogeneidad estructural, alargamiento destacable y su buena respuesta frente a las operaciones de mecanizado. Por otro lado, la extensa variedad de materias primas disponibles en las plantas de fundición supone un problema a la hora de controlar de forma efectiva la composición química de las aleaciones preparadas. En este trabajo se ha realizado un estudio estadístico sobre la influencia de los diferentes contenidos de carbono, silicio, níquel y de otros elementos minoritarios sobre las características estructurales y las propiedades mecánicas de un grupo de fundiciones con grafito esferoidal y matriz ferrítica. Finalmente, se han obtenido un número de ecuaciones que permiten predecir las propiedades mecánicas a temperatura ambiente de estas fundiciones en función de su composición química y su contenido de perlita en la matriz metálica.

PALABRAS CLAVE: Carbono; Fundiciones de hierro con grafito esferoidal y matriz ferrítica; Níquel; Propiedades mecánicas; Silicio

Copyright: (C) 2016 CSIC. This is an open-access article distributed under the terms of the Creative Commons Attribution License (CC BY) Spain 3.0. 


\section{INTRODUCTION}

Mechanical properties of ferritic spheroidal graphite cast irons (SGI) are very much sensitive to minor elements present due to alloying additions or the use of different raw materials. This has been investigated for long but the effect of the presence of some pearlite in the microstructure has seldom been considered in quantitative approaches. Accordingly, the optimum compositions which have been proposed (Watmough et al., 1971; Goodrich and Lobenhofer, 2002) were certainly in close relation to pearlite appearance as discussed previously (Sertucha et al., 2012). An exception is the work by Venugopalan and Alagarsamy (Venugopalan and Alagarsamy, 1990) who considered the matrix of cast-irons as a composite made of ferrite and pearlite. A so-called composite matrix microhardness $(\mathrm{CMMH})$ was defined as $\mathrm{CMMH}=\mathrm{HB}_{\alpha} \cdot \mathrm{f}^{\alpha}+\mathrm{HB}_{\mathrm{p}} \cdot \mathrm{f}^{\mathrm{p}}$ where $\mathrm{HB}_{\alpha}$ and $\mathrm{HB}_{\mathrm{p}}$ are the hardness of ferrite and pearlite respectively, and $\mathrm{f}^{\alpha}$ and $\mathrm{f}^{\mathrm{p}}$ are the fraction of ferrite and pearlite respectively. These authors observed that the CMMH parameter correlates linearly and satisfactorily with ultimate tensile strength UTS, yield strength $\mathrm{Y}$ and elongation at rupture A for the series of alloys they investigated. Such composite parameter has been defined and used also by Lunbäck and Svensson (Lundbäck and Svensson, 1991). However, these correlations were found to be highly scattered when several alloying elements are present in the alloys (Sertucha et al., 2012).

In recent years, the present authors have studied mechanical properties of three successive series of ferritic grades putting emphasis on the effect of alloying and low level elements (Sertucha et al., 2012), investigating more particularly the effect of nickel (Lacaze et al., 2012) and of silicon (De la Torre et al., 2014). All this information is used here to update the statistical analysis that was performed on the first series of results.

\section{EXPERIMENTAL INFORMATION}

All details on melt preparation and casting procedures have already been given (Lacaze et al., 2012; Sertucha et al., 2012; De la Torre et al., 2014). In the present work, only results obtained on materials cast in standard keel-blocks (type II according to EN 1563) and in as-cast state will be considered.

After solidification and cooling, one standard tensile specimen (10 $\mathrm{mm}$ in diameter) was machined from the lower part of each keel-block on which the ultimate tensile strength UTS, the rupture strain A and the yield strength $\mathrm{Y}$ were measured. Also, three impact energy specimens (KV type with dimensions $10 \times 10 \times 55 \mathrm{~mm}$ ) were also machined from the same area to determine impact strength at room temperature (RT), at $-20{ }^{\circ} \mathrm{C}$ and at $-40{ }^{\circ} \mathrm{C}$. Rectangular samples $(20 \times 30 \times 30 \mathrm{~mm}$ in size $)$ were also cut from keel-blocks and then their surface prepared for determining the Brinell hardness $\mathrm{HB}$ using a $10 \mathrm{~mm}$ diameter sphere and a load of $3000 \mathrm{~kg}$. Finally, the samples were cut and prepared for subsequent metallographic characterisation. The nodule count $\mathrm{N}_{\mathrm{A}}$ and the nodularity were evaluated by quantitative image analysis, while the fractions of ferrite $\mathrm{f}^{\alpha}$ and pearlite $\mathrm{f}^{\mathrm{p}}$ were determined by comparing the microstructure obtained after etching with 5\% Nital against standard reference microstructures (O’Brien et al., 1974; Ryntz, 1974). All iron samples analysed in this work showed a nodularity index higher than $90 \%$, while nodule count varied from 190 to $590 \mathrm{~mm}^{-2}$.

Table 1 shows the composition ranges of the three series for the elements that have been measured on all of them. In the first series, small levels of $\mathrm{B}, \mathrm{Bi}, \mathrm{Al}, \mathrm{Nb}, \mathrm{Ti}$ and $\mathrm{Zr}$ were also present, while $\mathrm{Cr}$ and Mo were at trace level in the two other series. Out of the 68 alloys of the first series (Sertucha et al., 2012), 9 showed the presence of coarse carbides and will be disregarded for the present study. Amongst the 59 remaining alloys, 31 had a pearlite content lower than $2 \%$ and will be considered as fully ferritic. In their as-cast state, the 6 alloys of the $\mathrm{Ni}$-series contained significant amounts of pearlite (Lacaze et al., 2012). Finally, 4 out of the 25 alloys in the Si-series showed a pearlite amount higher than 2\% (De la Torre et al., 2014). On the whole, the present analysis is going to be carried out on 52 fully ferritic alloys and 38 alloys showing amounts of pearlite ranging in between $3 \%$ and $33 \%$.

\section{STATISTICAL STUDY}

When applying the statistical analysis performed on the first series to the results obtained from the Si-series, predictions were found to give underestimated values as compared to experimental data. Owing to the high number of data available, it was decided to run a first statistical analysis only on fully ferritic alloys and then to include an additional term to account for the presence of pearlite in the other alloys.

For the ferritic part, and following our previous work, we looked at properties $\mathrm{P}_{\alpha}$ (Y, UTS, A or $\mathrm{HB}$ ) expressed as function of the nodule count $\left(\mathrm{N}_{\mathrm{A}}\right.$, expressed in $\left.\mathrm{mm}^{-2}\right)$ and of the composition $\left(\mathrm{w}_{\mathrm{i}}\right.$, where "i" stands for the various elements listed in Table 1, expressed in $w t \%$ ) allowing for the possibility of second order terms:

$$
\mathrm{P}_{\alpha}=\mathrm{a}_{0}+\mathrm{a}_{\mathrm{N}_{\mathrm{A}}} \cdot \mathrm{N}_{\mathrm{A}}+\mathrm{b}_{\mathrm{N}_{\mathrm{A}}} \cdot \mathrm{N}_{\mathrm{A}} \cdot \mathrm{N}_{\mathrm{A}}+\sum \mathrm{a}_{\mathrm{i}} \cdot \mathrm{w}_{\mathrm{i}}+\sum \mathrm{b}_{\mathrm{i}} \cdot \mathrm{w}_{\mathrm{i}} \cdot \mathrm{w}_{\mathrm{j}}
$$

All statistical analyses have been performed with the $\mathrm{JMP}^{\circledR}$ software, retaining those input variables that were found relevant at a risk of less than $5 \%$. The parameters thus obtained for fully ferritic alloys 
TABLE 1. Composition range of the three alloy series (wt.\%)

\begin{tabular}{lcccccccc}
\hline Series & $\mathbf{C}$ & $\mathbf{S i}$ & $\mathbf{M n}$ & $\mathbf{P}$ & $\mathbf{S}$ & $\mathbf{N i}$ & $\mathbf{C u}$ & $\mathbf{M g}$ \\
\hline $1^{\text {st }}$ series & 3.36 & 1.51 & 0.09 & 0.017 & 0.004 & 0 & 0.01 & 0.021 \\
& - & - & - & - & - & - & - & - \\
& 4.08 & 4.16 & 0.39 & 0.042 & 0.02 & 0.27 & 0.15 & 0.059 \\
\multirow{2}{*}{ Ni series } & 3.75 & 1.40 & 0.09 & 0.012 & 0.003 & 0.04 & 0.01 & 0.052 \\
& - & - & - & - & - & - & - & - \\
\multirow{2}{*}{ Si series } & 3.94 & 1.88 & 0.13 & 0.014 & 0.005 & 0.94 & 0.02 & 0.058 \\
& 3.02 & 2.20 & 0.05 & 0.016 & 0.005 & 0.030 & $<0.020$ & 0.033 \\
& - & - & - & - & - & - & - & - \\
& 3.84 & 3.81 & 0.11 & 0.032 & 0.009 & 0.073 & 0.052 & 0.060 \\
\hline
\end{tabular}

TABle 2. Coefficients obtained by multivariate analysis on Y, UTS, A and HB for fully ferritic alloys (Eq. (1)). Values of the present analysis are showed in bold, those of the previous analysis (Sertucha et al., 2012) are listed in normal font

\begin{tabular}{|c|c|c|c|c|c|c|c|c|c|c|}
\hline Property & Constant & $\mathbf{w}_{\mathrm{Si}}$ & $\mathbf{w}_{\mathrm{Ni}}$ & $\mathbf{w}_{\mathrm{C}}$ & $\mathbf{w}_{\mathrm{Cu}}$ & $\mathbf{w}_{\mathrm{S}}$ & $\mathbf{w}_{\mathrm{Si}} \cdot \mathbf{w}_{\mathrm{Si}}$ & $\mathbf{w}_{\mathrm{Si} \cdot \mathrm{wS}}$ & NA & $\mathbf{N}_{\mathbf{A}} \cdot \mathbf{N}_{\mathrm{A}}$ \\
\hline \multirow[t]{2}{*}{$\mathrm{Y}$} & 252.7 & -45.76 & 126.3 & & & & 26.78 & & & \\
\hline & 257.7 & -57.27 & 191.8 & & & & 28.34 & & 0.042 & \\
\hline \multirow{2}{*}{ UTS } & 511.3 & 82.47 & 101.2 & -70.00 & & & & & -0.049 & \\
\hline & 459.8 & -46.96 & 124.9 & -21.74 & -211.4 & & 23.28 & & 0.088 & \\
\hline \multirow[t]{2}{*}{ A } & 10.45 & 3.95 & -14.00 & & & & -1.25 & & 0.074 & $-8 \cdot 10^{-5}$ \\
\hline & 46.61 & -0.145 & -12.97 & -3.22 & & -1294 & -1.46 & 460.4 & 0.006 & \\
\hline \multirow[t]{2}{*}{$\mathrm{HB}$} & 295.7 & 31.63 & & -59.05 & -208.2 & & & & & \\
\hline & 85.92 & -23.37 & 40.46 & & & & 10.15 & & 0.299 & $-3.6 \cdot 10^{-4}$ \\
\hline
\end{tabular}

are listed in bold in Table 2 where they can be compared to those obtained with the previous analysis (Sertucha et al., 2012) in normal font. The $\mathrm{R}^{2}$ correlation coefficients were slightly lower than those previously obtained, but still quite high at $0.95,0.95$, 0.76 and 0.91 for Y, UTS, A and HB respectively. Predicted versus experimental values of Y, UTS, A and HB for fully ferritic alloys are plotted with solid symbols in the four graphs of Fig. 1.

It was then attempted to express the term due to pearlite such as to have a composite value written as $\mathrm{P}=\mathrm{f}^{\alpha} \cdot \mathrm{P}_{\alpha}+\mathrm{f}^{\mathrm{p}} \cdot \mathrm{P}_{\mathrm{p}}$ where $\mathrm{P}_{\mathrm{p}}$ would be a linear relation of input variables. The correlations thus obtained were quite poor, with $\mathrm{R}^{2}$ coefficients close to 0.50 . It finally appeared much more appropriate to write:

$\mathrm{P}=\mathrm{f}^{\alpha} \cdot \mathrm{P}_{\alpha}+\sqrt{\mathrm{f}^{\mathrm{p}}} \cdot \mathrm{P}_{\mathrm{p}}$

with:

$\mathrm{P}_{\mathrm{p}}=\mathrm{c}_{0}+\mathrm{c}_{\mathrm{N}_{\mathrm{A}}} \cdot \mathrm{N}_{\mathrm{A}}+\sum \mathrm{c}_{\mathrm{i}} \cdot \mathrm{w}_{\mathrm{i}}$

Value of the $\mathrm{R}^{2}$ correlation coefficient for the additional term $\mathrm{P}_{\mathrm{P}}$ was found higher than 0.70 for $\mathrm{Y}$, UTS and HB, and equal to 0.58 for $\mathrm{A}$. The $\mathrm{c}$ parameters are listed in Table 3 . Predicted values of
Y, UTS, A and HB for alloys containing some pearlite were evaluated using Eq. (2), and have been plotted versus experimental values in Fig. 1 with open symbols. It should be stressed that the values associated with these pearlite containing alloys are mainly located in the lower part of the clouds of points in the graphs of Fig. 1, i.e. they show low values of Y, UTS, A and hardness. This is directly related to the fact that these alloys are all comparatively low in silicon with a highest content at $2.6 \mathrm{wt} . \%$.

Plotting the properties $\mathrm{P}_{\mathrm{p}}$ as function of the pearlite content showed high scattering. No trend could be observed for Y and UTS while a slightly positive and a negative trend could be seen for $\mathrm{HB}$ and A respectively. This shows the low influence of the pearlite term on each of these properties for most of the studied alloys. However, the points appearing as outliers in the graphs of Fig. 1, with measured values much higher than those predicted, relate to two alloys with the highest amount of pearlite. This would mean that the correlations proposed to account for the presence of pearlite should be limited to pearlite fractions lower than $30 \%$, say $25 \%$ at most or so.

Figure 2 shows the correlation between impact energy for the three temperatures investigated $\left(\mathrm{RT},-20{ }^{\circ} \mathrm{C},-40{ }^{\circ} \mathrm{C}\right.$ ) and hardness measured at 
(a)

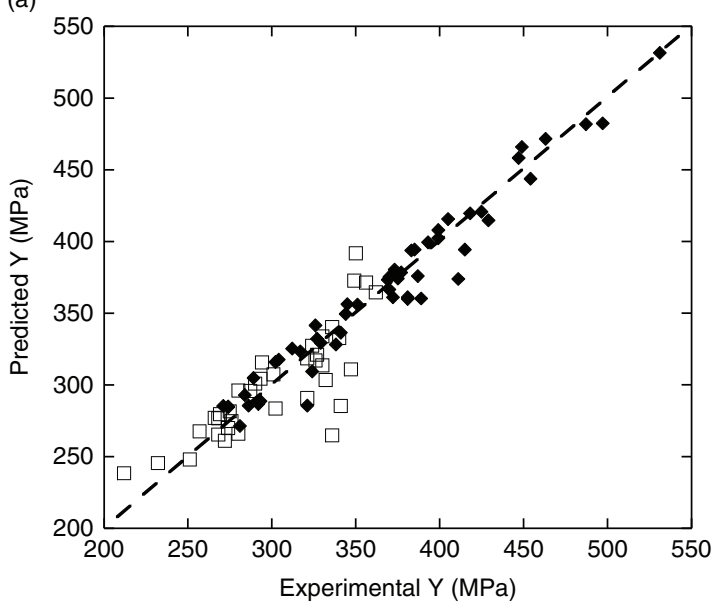

(c)

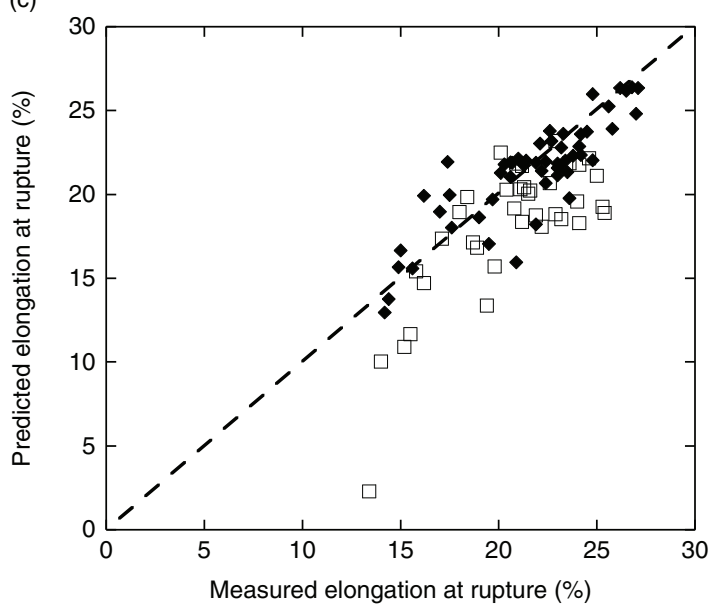

(b)

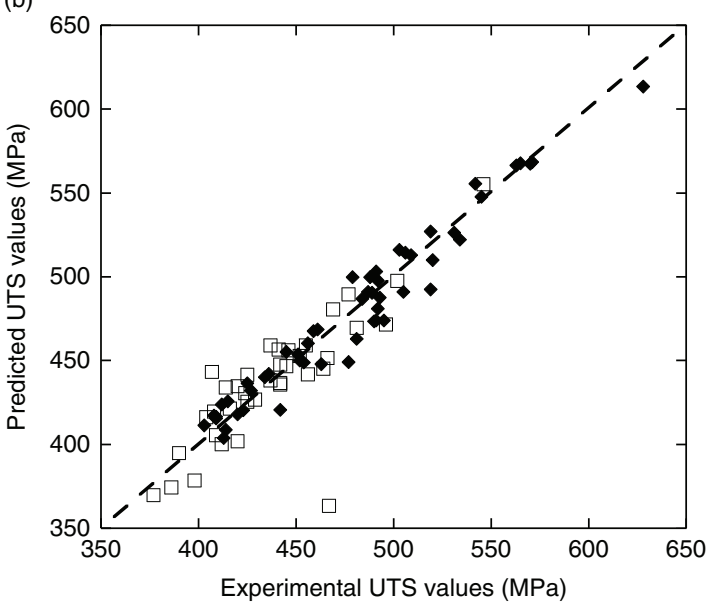

(d)

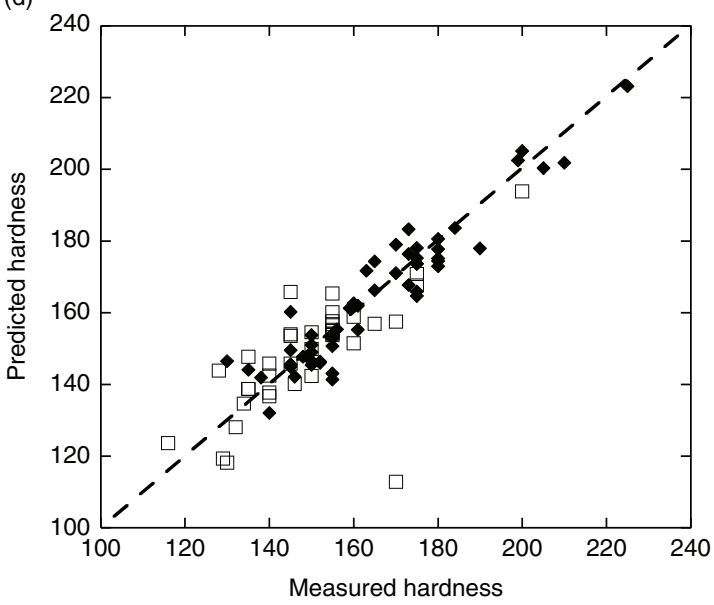

FIgurE 1. (a) Correlation between predicted and experimental values of Y, (b) UTS, (c) A and (d) HB. Solid symbols refer to fully ferritic alloys, open symbols to those containing more than $2 \%$ pearlite.

TABLE 3. Coefficients obtained by multivariate linear analysis for the pearlitic term $\left(\mathrm{P}_{\mathrm{p}}\right)$ of $\mathrm{Y}$, UTS, A and HB (Eq. (3))

\begin{tabular}{|c|c|c|c|c|c|c|c|c|c|c|}
\hline Property & Constant & $\mathbf{w}_{\mathrm{Si}}$ & $\mathbf{w}_{\mathrm{Ni}}$ & $\mathbf{w}_{\mathrm{C}}$ & $\mathbf{w}_{\mathrm{Cu}}$ & $\mathbf{w}_{\mathrm{Mn}}$ & $\mathbf{w}_{\mathbf{P}}$ & $\mathbf{w}_{\mathrm{S}}$ & $\mathbf{w}_{\mathrm{Mg}}$ & $\mathbf{N}_{\mathbf{A}}$ \\
\hline $\mathrm{Y}$ & 1126.8 & -105.0 & -219.6 & -188.5 & & 1151 & & & -4057 & -0.291 \\
\hline UTS & 1021 & -163.5 & & -196.0 & 1550 & 1143 & 4665.2 & & & -0.420 \\
\hline A & -127.6 & 11.0 & 27.3 & 29.9 & & -96.0 & & 1313 & & -0.074 \\
\hline HB & 471.5 & -67.2 & & -78.8 & 1169.7 & & & 3241 & & -0.213 \\
\hline
\end{tabular}

RT. The scatter is very high and only four alloys do have impact energy of at least $12 \mathbf{J}$ at a temperature of $-40{ }^{\circ} \mathrm{C}$ as for EN-GJS-350-22-LT grade. As expected, these alloys have a low silicon content, here lower than $2.1 \mathrm{wt} . \%$, but also low sulfur $(0.005$ to 0.008 wt. $\%)$ and phosphorus (0.012 to 0.024 wt.\%) contents. As noted previously (Sertucha et al., 2012), alloys with similar Si contents but higher $\mathrm{S}$ and $\mathrm{P}$ contents showed significantly lower impact energies.

Previous statistical analysis (Sertucha et al., 2012) on impact energy as function of composition for fully ferritic alloys gave correlation coefficients close to $R^{2}=0.80$. However, if the effect of sulfur appeared statistically significant, it was not the case for phosphorus. The same occurred with the present enlarged series of data. Furthermore, the previous analysis on the first series (Sertucha et al., 2012) showed also a very significant effect of both $\mathrm{B}$ and $\mathrm{N}$ in reducing impact properties. The content in these elements was unfortunately not measured in the two following series. Accordingly, the $\mathrm{R}^{2}$ coefficient then obtained without accounting for $\mathrm{B}$ and $\mathrm{N}$ were found in the present work to be lower than 0.70 . These analyses are thus of little interest and are not reported. 


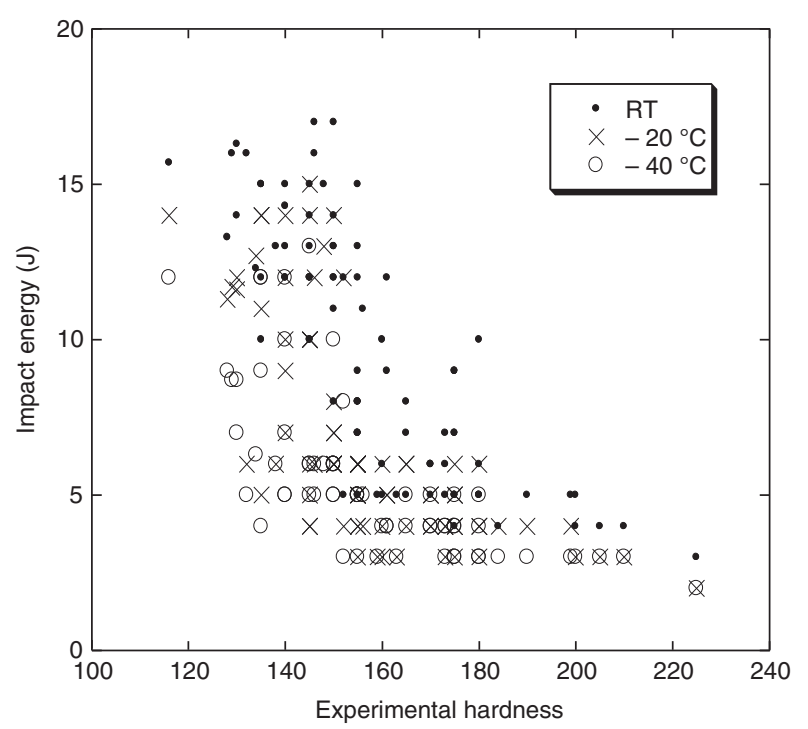

FIGURE 2. Experimental values of impact energy at the three investigated temperatures plotted versus experimental hardness at RT.

\section{DISCUSSION}

RT mechanical properties are firstly determined by alloy's silicon content which has a non linear effect on ferrite properties (see Table 2). Figure 3a shows the experimental change of Y, UTS and HB with silicon content and Fig. $3 \mathrm{~b}$ that of elongation at rupture, both plots made with all data, i.e. including alloys showing some pearlite.

On these graphs it has also been drawn the predicted evolution of the mechanical properties using the model for fully ferritic alloys (Eq. (1)). Dotted lines relate to alloys containing only silicon with carbon at $3.5 \mathrm{wt} . \%$ and a nodule count of $300 \mathrm{~mm}^{-2}$. To draw solid lines, extra additions of $0.1 \mathrm{wt} . \%$ of both $\mathrm{Cu}$ and $\mathrm{Ni}$ and of $0.01 \mathrm{wt} . \% \mathrm{~S}$ were considered.

Comparing the predicted values of Y, UTS and HB (Fig. 3a) for pure Fe-C-Si cast irons (dotted lines) and alloyed ones (solid lines) it is observed a very little sensitivity to low-level alloying. This is in agreement with the low scatter of the regressions observed in Fig. 1 for fully ferritic alloys. In other words, the alloying elements seem to have little influence on mechanical properties for irons that are basically ferritic. Higher additions and the possible presence of pearlite shows scattering of the data, mainly by leading to values significantly above the prediction for Y, UTS and HB.

Contrarily, Fig. $3 \mathrm{~b}$ shows that A is comparatively much more sensitive to the presence of alloying elements than the other three mechanical properties. A pure $\mathrm{Fe}-\mathrm{C}-\mathrm{Si}$ alloy leads to poor prediction with too high elongation values at low silicon contents when compared to the experimental data. Interestingly, it is seen that the low level additions considered for the alloyed irons (solid line) fits to the upper limit of the experimental data range. In turn, this means that any higher addition of alloying elements or any pearlite present in the as-cast material would strongly decrease the actual value of A. If these additions are limited as in the present study, data in Fig. 3 shows that the alloys at high silicon content fulfil the new standard EN 1563 (Stets et al., 2013).

Figure 4 compares the measured impact energy of fully ferritic alloys to that predicted with the regression analysis previously reported (Sertucha (a)

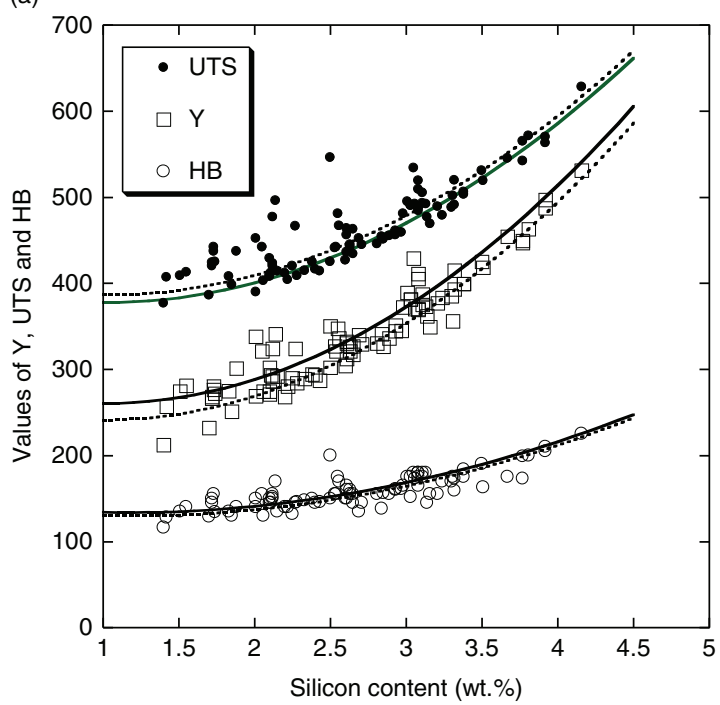

(b)

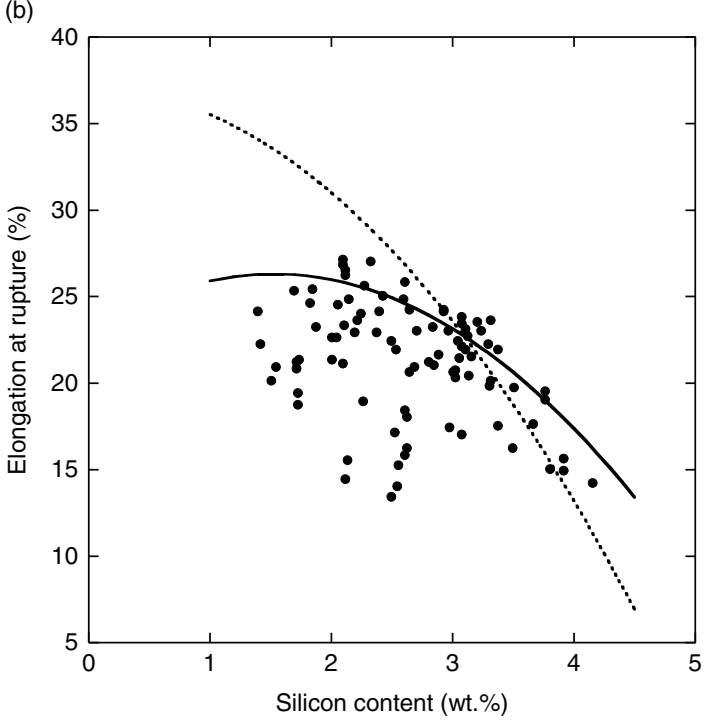

FIGURE 3. Effect of silicon content on the RT mechanical properties of studied cast irons: (a) Y, UTS and HB; and (b) A. Symbols are the experimental data, doted lines are calculated for an average carbon content of $3.5 \mathrm{wt} . \%$ and a nodule count of $300 \mathrm{~mm}^{-2}$; solid lines are calculated accounting for other relevant elements $(\mathrm{Cu}: 0.1, \mathrm{Ni}: 0.1$ and $\mathrm{S}: 0.01, \mathrm{wt} . \%)$. 


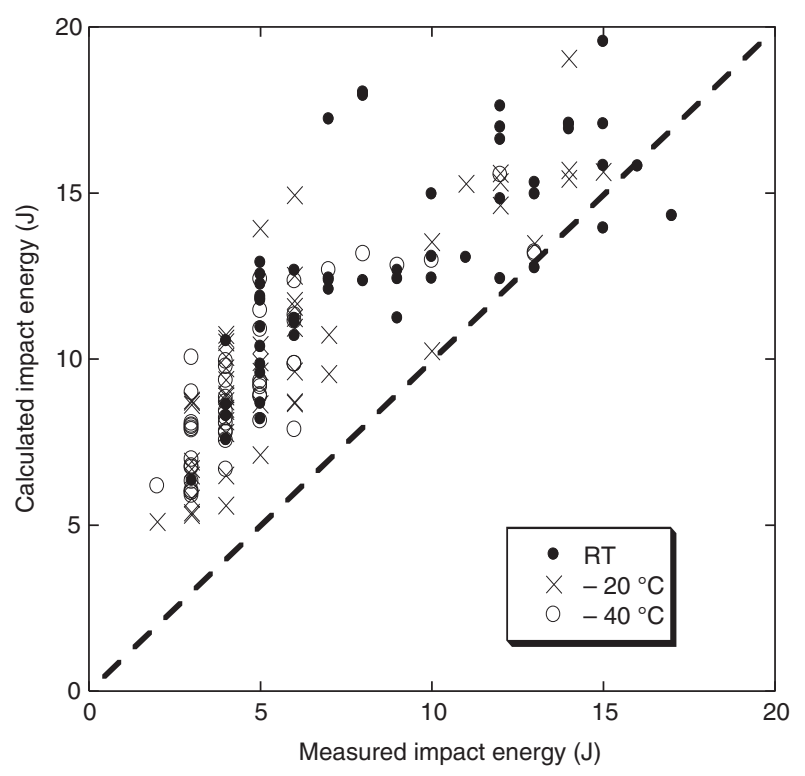

FIGURE 4. Comparison of experimental and calculated impact energies for fully ferritic alloys.

et al., 2012). It is seen that the predicted values are much higher than the experimental ones, and this is due to the fact that $\mathrm{B}$ and $\mathrm{N}$ contents were not included in the present calculations. These trace elements and impurities $(\mathrm{B}, \mathrm{N}, \mathrm{S})$ show interactions with alloying elements $(\mathrm{Cu}, \mathrm{Mn}, \mathrm{Ti})$ that were not statistically significant in the present analysis but strong enough to show up. For both impact energy and RT tensile properties and hardness, the strong effect of these very low level elements would be worth of further analysis.

In a preceding work (Sertucha et al., 2012), the effect of some other low level alloying elements such as $\mathrm{Zr}$ could be statistically analyzed. Unfortunately, all these low level elements were not measured in the two other series and had to be disregarded in the present analysis. Also, a strong interaction between $\mathrm{S}$ and $\mathrm{Ti}$ and a two-fold correlation among $\mathrm{N}_{\mathrm{A}}, \mathrm{S}$, $\mathrm{Cu}$ and $\mathrm{Ti}$ were previously observed. Similar correlations could be noted in the present analysis between elements such as $\mathrm{S}, \mathrm{P}, \mathrm{Cu}, \mathrm{Mg}$ and $\mathrm{Mn}$, even though they were not statistically significant.

\section{CONCLUSIONS}

A set of 90 different nodular cast irons have been used for updating a previous statistical study dedicated at predicting RT mechanical properties. The new statistical analysis suggests expressing any property $\mathrm{P}$ (Y, UTS, A and $\mathrm{HB}$ ) using the equation $\mathrm{P}=\mathrm{f}^{\alpha} \cdot \mathrm{P}_{\alpha}+\left(\mathrm{f}^{\mathrm{p}}\right)^{0.5} \cdot \mathrm{P}_{\mathrm{p}}$, where $\mathrm{P}_{\alpha}$ and $\mathrm{P}_{\mathrm{p}}$ correspond to ferrite and to pearlite properties respectively, and $\mathrm{f}^{\alpha}$ and $\mathrm{f}^{\mathrm{p}}$ are the fractions of ferrite and pearlite respectively. Correlation between predicted and experimental values of each property shows that the pearlite term relevantly affects A while its effect on the other properties becomes small.

Evolution of RT mechanical properties with $\mathrm{Si}$ content indicates that the presence of minor alloying elements $(\mathrm{Cu}, \mathrm{Mn}, \mathrm{Ni}, \mathrm{P}$ and $\mathrm{S})$ has a quite limited effect on Y, UTS and hardness of mainly ferritic cast iron alloys. On the contrary, A is more sensitive to the presence of these alloying elements and shows a significant decrease when their content is increased.

\section{ACKNOWLEDGEMENTS}

The present paper was originally presented in the World Foundry Congress 2014 in Bilbao (Spain). The World Foundry Organization is acknowledged for authorization to make it available to a larger audience. The authors also thank Thermal Quality Control S.L.U. for all collaborating efforts made in the experimental trials.

\section{REFERENCES}

De la Torre, U., Loizaga, A., Lacaze, J., Sertucha, J. (2014). Ascast high silicon ductile irons with optimised mechanical properties and remarkable fatigue properties. Mater. Sci. Tech. 30 (12), 1425-1431. http://dx.doi.org/10.1179/17432 84713Y.0000000483.

Goodrich, G.M., Lobenhofer, R.W. (2002). Effect of cooling rate on ductile iron mechanical properties. AFS Trans. 110 , paper $02-137$.

Lacaze, J., Larrañaga, P., Asenjo, I., Suarez, R., Sertucha, J. (2012). Influence of $1 \mathrm{wt}-\%$ addition of $\mathrm{Ni}$ on structural and mechanical properties of ferritic ductile irons. Mater. Sci. Tech. 28 (5), 603-608. http://dx.doi.org/10.1179/17432 84711 Y.0000000100.

Lundbäck, E., Svensson, I.L. (1991). Prediction of properties of nodular cast iron castings, by means of computer simulation. Proceedings MCWASP V, Eds. Rappaz, M., Ozgu, M.R., Mahin, K.W., TMS, pp. 479-484.

O'Brien, J., Adams, A., Avedisian, A., Barnes, G.J., Booth, B.N., Dubberstein, G., House, W., Janowak, J.F., Langner, E.E., Lansing, J.H., Lee, R.S., Nelson, C.D., Parks, T.W., Peacock, J.H., Thomson, R.S., Vanik, J.S., Warrick, R.J. (1974). Reference microstructure for measurement of pearlite and ferrite content in ductile iron microstructures. AFS Trans. 82, 545-550.

Ryntz, E.F. (1974). Reference microstructures for visual estimation of iron carbide content in nodular iron. AFS Trans. $82,551-554$.

Sertucha, J., Lacaze, J., Serrallach, J., Suárez, R., Osuna, F. (2012). Effect of alloying on mechanical properties of as cast ferritic nodular cast irons. Mater. Sci. Tech. 28 (2), 184-191. http:// dx.doi.org/10.1179/1743284711Y.0000000014.

Stets, W., Löblich, H., Gassner, G., Schumacher, P. (2013). Solution strengthened ferritic ductile cast iron according DIN EN 1563:2012 properties, production and application. Proceedings Keith Millis Symposium, Nashville, USA.

Venugopalan, D., Alagarsamy, A. (1990). Effects of alloy additions on the microstructure and mechanical properties of commercial ductile iron. AFS Trans. 98, 395-400.

Watmough, T., Shaw, W.F., Bock, F.C. (1971). Combined effects of selected elements on the properties of ductile iron. AFS Trans. 79, 225-246. 